\title{
Effect of Glyphosate on Performance of Faba Bean Varieties Under Heavy Infestation of Orobanche crenata
}

\author{
Mahmoud M. Zeid ${ }^{* 1}$ and Mona M. Hemeid ${ }^{1}$
}

\begin{abstract}
Orobanche crenata is a devastating parasitic weed on faba bean with its effects not confined to the Mediterranean region anymore. This study investigated the effect of number of glyphosate sprays, at the rate of $86 \mathrm{~g}$ a.i./ha, on the performance of a set of faba bean varieties varying in their resistance to the parasite under farmer's field conditions. The main target was to find out whether faba bean resistance coupled with glyphosate application could be adopted as standard procedure for efficiently combating the parasite. Results indicated that, under current farmer's field conditions, spraying resulted in a clear reduction in the number of emerged spikes from 18 to 49\% and the amount of photo-assimilates accumulated by the parasite from 1 to $42 \%$, depending on the variety and that was related to the number of sprays applied. There was no improvement in faba bean yield associated with the reduction in infestation under glyphosate sprays compared to the control, even with the most resistant faba bean varieties known in Egypt; namely Giza 843, Misr 1 and Misr 3. Considering its cost and impact on human health, glyphosate is not recommended for infested faba bean fields. In heavily infested fields, it is recommended to employ other integrated pest management protocols that aim at reducing the parasite seed bank per se before considering any winter pulses. This halt on winter pulses is essential to deplete the seed bank and prevent further spread of the parasite and should continue until a better technology to combat the parasite evolves. The new Misr 3 was seen here as a very promising variety that generally combines both good yield and low number of emerged spikes compared to older varieties Giza 843 and Misr 1.
\end{abstract}

KEY WORDS: hormesis; parasite; broomrape; resistance; Vicia faba.

\section{INTRODUCTION}

Faba bean is one of the widely consumed pulses in the Mediterranean region but major production areas in 2017 were China, Ethiopia and Australia (FAO 2019). In Egypt, the crop represents the main source of protein for the majority of the population, simply because it is the cheapest protein source, not only compared to animal sources, but also among other pulses. Despite the fact that in the 1970's self-sufficiency from faba bean in Egypt was estimated to be $115 \%$ (Nassib et al. 1991), this figure has been dropping drastically since the
1980 's, reaching $35 \%$ or less in 2018. As a matter of fact Egypt is currently the major importer of faba bean worldwide, receiving 480,000-520,000 tons split between Australia and UK and representing 70\% of Australia's export market (Poutney 2014). The drop in self-sufficiency is mainly due to the decline in the cultivated area from 152,000 ha in 1961 to a record low of 32,500 in 2017 (FAOSTAT 2019). This $79 \%$ reduction in the cultivated area could be attributed to the rising costs of production compared to other winter crops namely; wheat and berseem clover, those two crops fetch higher market price of the produce than faba bean, in addition to the influence of the cheap imported faba beans on the market. Another major issue that keeps winter pulses including faba bean off the fields is the spread of O.crenata and the buildup of a long lasting seed bank. Besides the known methods of spread of the parasite, special activities of Egyptian farmers have intensified the problem. The transfer of infested clay and manure from the Nile delta to newly cultivated sandy soils with the aim of improving water holding capacity, grazing of faba bean fields destroyed by the parasite with standing mature spikes, in an attempt to cut back on income losses and on-field threshing of faba bean along with O.crenata spikes, are all activities that have widely spread the parasite and enriched the soil seed bank lavishly. As a result, Egyptian farmers were forced to abandon growing winter pulses due to O.crenata heavy soil infestation. The O.crenata problem is not confined to Egypt or the Mediterranean region as has always been thought, it has rather spilled out of the basin and reports of huge losses are coming from as far as Ethiopia (Misganaw 2016) in the South and as far as UK in the North, where recent field infestations have been reported (Parker 2013). Control measures to combat the parasite are numerous, including resistant varieties, trap crops, chemical and biological control etc.; however, none was capable of providing a satisfactory solution. Integrated broomrape management has been suggested as the best approach to tackle this problem but the challenges, including ineffective dissemination and adoption of the technologies, have hindered success (Abang et al. 2007), and up to date no true remedy to the problem has been put forward. Resistant plant

DOI: 10.21608/ASEJAIQJSAE.2019.29840

${ }^{1}$ Department of Crop Science, Faculty of Agriculture,

Alexandria University, Alexandria, Egypt.

* Corresponding author's email: mahmoud.zeid@alexu.edu.eg

Received March 3, 2019, Accepted March30, 2019 
material is known to be the most effective and least expensive method of combating pests. Egypt has been very successful in breeding faba bean varieties expressing a good level of resistance to O.crenata starting with the earliest variety Giza 402 (Nassib et al. 1982) and most recently the variety Misr 3 (Attia et al. 2013).

Glyphosate, a post-emergence, non-selective, systemic herbicide, inhibits a key enzyme in the aromatic amino acids biosynthesis pathway in plants. Once sprayed on plant foliage, the toxin gets translocated to the plant sink tissues in roots, rhizomes, seeds and tubers. In faba bean it is recommended to spray glyphosate as flowering is initiated. Around that time O.crenata seed germination would have been triggered by the faba bean root exudates and germinated seeds would have attached themselves using the haustorium. Once successful in root penetration, the haustorium becomes the physiological connection between the parasite and faba bean, channeling water and photo-assimilates to the parasite, thus creating a new strong sink below the soil surface (Arjona-Berral et al. 1990). At this delicate phase, if pod filling has already been initiated on the faba bean plant, partitioning of assimilate between the two sinks (parasite and the pod) occurs, however, if pod filling was not achieved by that time, the below-ground sink (parasite) suppresses the formation of the above-ground sink (pods) as indicated by Manschadi et al. (1997). It is at this critical phase, that when glyphosate is introduced to the host in low concentrations, translocation of the herbicide molecules was observed to be greater in the direction of the haustorium leading to the accumulation of the herbicide in the parasite tissue causing growth disruption (ArjonaBerral et al. 1990). This however, comes at an expense, where signs of phytotoxicity effects of the herbicide start showing on the faba bean plants, including leaf wrinkling and chlorosis (Mesa-Garcia et al. 1984). Fortunately, these effects could be reversed by improving the host's nutritional status after spraying (Shaban et al. 1987).

Reports of employing glyphosate for O.crenata control in faba bean are numerous. Mesa-Garcia et al. (1984) tested a series of glyphosate applications (60, 120 and $240 \mathrm{~g}$ a.i./ha in single or double applications, 2 weeks apart) and obtained excellent control of the parasite at the rate of $60 \mathrm{~g}$ a.i./ha. Jacobsohn and Kelman (1980), reported that besides controlling the parasite, an improvement in yield compared to the unsprayed checks was achieved when applying 2-3 sprays at the rate of $150 \mathrm{~g}$ a.i./ha. Similarly, in Egypt, using susceptible varieties (Kandil et al. 2015; Zahran et al. 1980) and the resistant variety Giza 843 (Ghalwash et al. 2012), good control of the parasite was achieved when spraying about $86 \mathrm{~g}$ a.i./ha of glyphosate. In addition, plant height, vegetative weight and seed yield were improved due to spraying as compared to the unsprayed control under O.crenata infestation. On the other hand, Sauerborn et al. (1989), in Syria, achieved nearly complete control of the parasite at $80 \mathrm{~g}$ a.i./ha sprayed twice, but no improvement in faba bean vegetative traits or yield was observed.

The aim of this study was to investigate the effect of glyphosate sprays on the performance of a set of faba bean varieties varying in their resistance to the parasite under farmer's field conditions and to try to understand whether a resistant faba bean variety coupled with glyphosate application could be adopted as standard procedure for combating the parasite efficiently.

\section{MATERIAL AND METHODS}

The effect of the number of glyphosate sprays on growth and production of faba bean varieties and on O.crenata parasitism in a naturally infested field was studied during the 2014/2015 and 2015/2016 growing seasons. The field was located in Kafr El-Dawar, Beheira governorate and was characterized by sandy clay loam type of soil. The field was selected a year prior to the experiments when it was grown with faba bean and the O.crenata growing there was observed to be homogenously distributed and quite aggressive while neighboring areas were O.crenata free, due to threshing of infested plants in that specific part of the field. Sowing was performed on the $9^{\text {th }}$ of November and harvesting was on the $16^{\text {th }}$ of April in both seasons. Phosphorus fertilizer was incorporated into the soil during field preparation in the form of calcium super phosphate $\left(15.5 \% \quad \mathrm{P}_{2} \mathrm{O}_{5}\right)$ at the rate of $48 \mathrm{~kg} / \mathrm{ha}$ and no other ground fertilizers were employed, so as not to interfere with the experiment results. Single seeds were sown in hills $25 \mathrm{~cm}$ apart on one side of the ridge. In a split plot experiment, the subplots made up of three ridges, $60 \mathrm{~cm}$ apart and 3 meters in length each, were assigned to each of the studied faba bean varieties, while the main plots were assigned to the glyphosate rates. In the first season, the experiment comprised three glyphosate sprays $(0$, i.e. water was applied, 1 and 2 sprays) and 4 faba bean varieties (Giza 402, Giza 843, Misr 1 and Nubaria 3) in 4 replicates. In the second season, however, only 3 replicates were tested with an additional $3^{\text {rd }}$ glyphosate spray and 3 additional faba bean varieties (Nubaria 1, Giza 3 and Misr 3). Giza 402, Giza 843 , Misr 1 and Misr 3 are all O.crenata resistant varieties (Attia et al. 2013; Zeid et al. 2009), while Nubaria 1, Nubaria 3 and Giza 3 are susceptible, late flowering varieties. 
The first glyphosate spray was employed when faba bean flowering was observed on the resistant varieties (55 days from sowing) using glyphosate at the rate of $86 \mathrm{~g}$ a.i./ha, according to the recommendation of the Central Administration for Agricultural Extension Service, Egypt, (CAAES 2014) and the following sprays were applied 2 weeks apart. Five days after each glyphosate spray, a foliar application of "Nile Flor" from Strading S.R.L., $\left(3.1 \% \mathrm{~N}, 1 \% \mathrm{P}_{2} \mathrm{O}_{5}, 2 \% \mathrm{~K}_{2} \mathrm{O}, 200\right.$ ppm $\mathrm{Mg}, 100 \mathrm{ppm} \mathrm{Zn,} 30 \mathrm{ppm} \mathrm{Cu}, 0.01 \% \mathrm{~B}$ and 6\% free amino acids) was sprayed on the entire field to reduce any phytotoxic effects on the host. At harvest, data on faba bean plant height $(\mathrm{cm})$, vegetative biomass $(\mathrm{g})$ and pod weight $(\mathrm{g})$ were recorded from one meter of the middle guarded ridge after drying. The number of emerged O.crenata spikes/plant and O.crenata dry weight $(\mathrm{g})$, were recorded after uprooting the host plants in one metered ridge. Total biomass was calculated by summing the faba bean vegetative biomass, pod weight and weight of the attached O.crenata plants.

Statistical analysis of variance was performed using SAS 9.3 software (SAS 2007) for each year separately. Significance was declared at $\mathrm{P}<0.05$, and the least significant difference (L.S.D $D_{0.05}$ ) was used for comparison of means.

\section{RESULTS AND DISCUSSION}

The first glyphosate spray was applied when flowering started in the resistant early faba bean group (55 days from sowing). The susceptible group on the other hand, flowered 80 days from sowing, but received the glyphosate sprays early along with the resistant group (as local farmers usually do). Because of that, data from each group were separately analyzed; however, since trends on effect of spraying were consistent among the two groups, data were analyzed for both groups and presented together. The interaction between number of sprays and varieties was insignificant for all traits in both seasons (Tables 1 and 2 ); accordingly each of the studied factors will be presented separately.

\section{Effect of number of glyphosate sprays:}

A reduction in the number of O.crenata emerged spikes/plant was observed with the increase in the number of glyphosate sprays compared to the control in both seasons (Tables 3 and 4). In season 1 the reduction in number of emerged spikes was significant and amounted to 18.1 and $22.3 \%$ for one and two sprays compared to the control, respectively (Table 3). For season 2, the reduction in number of spikes amounted to 24.2 and $28.1 \%$ for one and two sprays, respectively, but was not significantly different from the control. The three sprays, on the other hand, caused a $49 \%$ reduction in the number of spikes/plant and were significantly different from the control (Table 4). Regarding the amount of photo-assimilates accumulated by the parasite, expressed here as O.crenata weight $/ \mathrm{m}$, the one spray showed insignificant differences from the control in both seasons (Tables 3 and 4). The two sprays in seasons 1 and 2 and the three sprays in season 2 showed 1,31 and $42 \%$ significant reduction in assimilates accumulated by the parasite, respectively. A negative effect for the glyphosate spraying treatments on faba bean plant height, vegetative weight $/ \mathrm{m}$ and pod weight $/ \mathrm{m}$ compared to the unsprayed control was observed in both seasons, with a general trend for a decrease in all trait values with the increase of the number of sprays applied (Tables 3 and 4).The reduction in vegetative weight in both seasons, pod weight $/ \mathrm{m}$ in season 1 and plant height in season 2, was statistically insignificant from the control. Although, not significantly different from the control, both vegetative weight $/ \mathrm{m}$ and pod weight $/ \mathrm{m}$ in season 2 exceptionally showed an increase of $8.5 \%$ and $25 \%$ over the control when a single spray was applied, respectively (Table 4). At the same time an improvement of $6.9 \%$ in total biomass $/ \mathrm{m}$ and a reduction in O.crenata weight $/ \mathrm{m}$ by $14.5 \%$ was observed due to the single glyphosate application, indicating a better control of the parasite. Further sprays brought about reduction in total biomass, pod weight and O.crenata weight indicating phytotoxicity (Table 4). These results clearly indicated that glyphosate reduced parasite infestation, and the reduction was a factor of the number of spray treatments applied, however, this was not coupled with a significant improvement in either faba bean vegetative growth or productivity as compared to the control. Similarly, Sauerborn et al. (1989) achieved up to 99\% reduction in number of O.crenata emerged shoots with $80 \mathrm{~g}$ a.i./ha applied twice, this was coupled by $19 \%$ reduction in faba bean plant height and $28 \%$ in seed yield compared to the control. Also Nadal et al. (2005), in Spain, sprayed the determinate cultivar "Retaca" with glyphosate at the rate of 67 and $201 \mathrm{~g}$ a.i./ha in a heavily infested field. Spraying showed to be insignificantly different from the unsprayed control under both rates, except for one year when spraying with $67 \mathrm{~g}$ a.i./ha outyielded the control by 54\%. Mesa-Garcia et al. (1984) observed that glyphosate rate of $120 \mathrm{~g}$ a.i./ha did not affect seed yield at two locations in Spain, however, in a third location a reduction of $15 \%$ in yield was recorded. In Egypt, on the other hand, El-Metwally et al. (2013), El-Rokiek et al. (2015), Ghalwash et al. (2012) and Kandil et al. (2015), employing the recommended rate of $86 \mathrm{~g}$ a.i./ha glyphosate, observed a good control of O.crenata and at the same time an increase in plant height and in seed yield (19 to 58\%) with increasing the 
Table 1. Mean squares and levels of significance for faba bean and $O$.crenata traits as affected by number of glyphosate sprays (A) and faba bean varieties (B) in the 2015 growing season (season 1)

\begin{tabular}{|c|c|c|c|c|c|c|c|c|c|}
\hline S.O.V & d.f & $\begin{array}{l}\text { Plant } \\
\text { height }\end{array}$ & $\begin{array}{l}\text { Number of } \\
\text { days to } \\
\text { flowering }\end{array}$ & $\begin{array}{l}\text { Faba bean } \\
\text { vegetative } \\
\text { weight }\end{array}$ & $\begin{array}{c}\text { Pod } \\
\text { weight }\end{array}$ & $\begin{array}{l}\text { Faba bean } \\
\text { biological } \\
\text { weight }\end{array}$ & $\begin{array}{l}\text { O. crenata } \\
\text { weight }\end{array}$ & $\begin{array}{l}\text { Total } \\
\text { biomass }\end{array}$ & $\begin{array}{l}\text { No. of } \\
\text { O.crenata } \\
\text { spikes/plant }\end{array}$ \\
\hline Replicate (Rep.) & 3 & 734.87 & 1.154 & 0.146 & 0.0073 & 0.2031 & 0.0161 & 0.293 & 0.07 \\
\hline No. Sprays (A) & 2 & $1459.43^{*}$ & $0.106^{\text {n.s. }}$ & $0.064^{\text {n.s. }}$ & $0.0023^{\text {n.s. }}$ & $0.0879^{\text {n.s. }}$ & $0.0199^{*}$ & $0.191^{\text {n.s. }}$ & $3.839^{* *}$ \\
\hline Error a & 6 & 141.09 & 0.106 & 0.173 & 0.0052 & 0.2366 & 0.0041 & 0.205 & 0.229 \\
\hline Varieties (B) & 3 & $749.61^{* *}$ & $11.26^{* *}$ & $0.946^{* *}$ & $0.0276^{* *}$ & $1.2775^{* *}$ & $0.0975^{* *}$ & $1.159^{* *}$ & $8.15^{* *}$ \\
\hline $\mathrm{AxB}$ & 6 & $56.75^{\text {n.s. }}$ & $0.065^{\text {n.s. }}$ & $0.014^{\text {n.s. }}$ & $0.0010^{\text {n.s. }}$ & $0.01894^{\text {n.s. }}$ & $0.0057^{\text {n.s. }}$ & $0.021^{\text {n.s. }}$ & $0.186^{\text {n.s. }}$ \\
\hline Error b & 27 & 35.16 & 0.207 & 0.035 & 0.0015 & 0.0455 & 0.0072 & 0.537 & 0.363 \\
\hline
\end{tabular}

Table 2. Mean squares and levels of significance for faba bean and O.crenata traits as affected by number of glyphosate sprays (A) and faba bean varieties (B) in the 2016 growing season (season 2)

\begin{tabular}{|c|c|c|c|c|c|c|c|c|c|}
\hline S.O.V & d.f & $\begin{array}{l}\text { Plant } \\
\text { Height }\end{array}$ & $\begin{array}{l}\text { Number } \\
\text { of days } \\
\text { to } \\
\text { flowerin }\end{array}$ & $\begin{array}{l}\text { Faba bean } \\
\text { vegetative } \\
\text { weight }\end{array}$ & $\begin{array}{l}\text { Pod } \\
\text { weight }\end{array}$ & $\begin{array}{l}\text { Faba bean } \\
\text { biological } \\
\text { weight }\end{array}$ & $\begin{array}{l}\text { O. crenata } \\
\text { weight }\end{array}$ & $\begin{array}{l}\text { Total } \\
\text { biomass }\end{array}$ & $\begin{array}{l}\text { No. of } \\
\text { O.crenata } \\
\text { spikes/plant }\end{array}$ \\
\hline $\begin{array}{l}\text { Replicate } \\
\text { (Rep.) }\end{array}$ & 2 & 709.82 & 0.068 & 775.58 & 396.62 & 2252.39 & 28.53 & 2743.45 & 6.89 \\
\hline No. Sprays (A) & 3 & $229.48^{\mathrm{n} . \mathrm{s}}$ & $0.085^{\mathrm{n} . \mathrm{s}}$ & $30.64^{\mathrm{n} . \mathrm{s}}$ & $115.66^{*}$ & $250.9^{* *}$ & $85.04^{*}$ & $517.68^{*}$ & $27.01^{*}$ \\
\hline Error a & 6 & 459.52 & 0.062 & 47.36 & 24.60 & 108.33 & 9.64 & 80.76 & 7.00 \\
\hline Varieties (B) & 6 & 501.01 & 15.55 & 309.42 & 820.66 & 1959.58 & 104.88 & $2050.15^{* *}$ & 38.49 \\
\hline $\mathrm{AxB}$ & 18 & $129.37^{\mathrm{nss}}$ & $0.06^{\mathrm{n} . \mathrm{s}}$ & $42.51^{\text {n.s }}$ & $47.07^{\mathrm{n} . \mathrm{s}}$ & $138.23^{\mathrm{n} . \mathrm{s}}$ & $21.12^{\mathrm{n} . \mathrm{s}}$ & $231.10^{*}$ & $5.11^{\mathrm{n} . \mathrm{s}}$ \\
\hline Error b & 48 & 65.36 & 0.063 & 34.76 & 34.44 & 77.75 & 16.51 & 107.27 & 3.69 \\
\hline
\end{tabular}

*Significant at 0.05 level of probability, **Significant at 0.01 level of probability, n.s.: Not-significant

Table 3. Means for plant height, faba bean vegetative weight $/ \mathrm{m}^{*}$, pod weight $/ \mathrm{m}$, O.crenata weight $/ \mathrm{m}$ total biomass $/ \mathrm{m}$ and number of spikes/plant as affected by number of glyphosate sprays and faba bean variety for the 2015 growing season (season 1)

\begin{tabular}{ccccccc}
\hline No. sprays & $\begin{array}{c}\text { Plant } \\
\text { height } \\
(\mathbf{c m})\end{array}$ & $\begin{array}{c}\text { Faba bean } \\
\text { vegetative } \\
\text { weight }\left(\mathbf{g} / \mathbf{m}^{*}\right)\end{array}$ & $\begin{array}{c}\text { Pod } \\
\text { weight } \\
(\mathbf{g} / \mathbf{m})\end{array}$ & $\begin{array}{c}\text { O.crenata } \\
\text { weight } \\
(\mathbf{g} / \mathbf{m})\end{array}$ & $\begin{array}{c}\text { Total } \\
\text { biomass } \\
(\mathbf{g} / \mathbf{m})\end{array}$ & $\begin{array}{c}\text { No. of } \\
\text { o.crenata } \\
\text { spikes/plant }\end{array}$ \\
\hline Control & $89.15 \mathrm{a}$ & $14.76 \mathrm{a}$ & $10.11 \mathrm{a}$ & $8.21 \mathrm{a}$ & $33.07 \mathrm{a}$ & $14.59 \mathrm{a}$ \\
1 spray & $73.99 \mathrm{~b}$ & $14.69 \mathrm{a}$ & $10.11 \mathrm{a}$ & $8.16 \mathrm{ab}$ & $32.97 \mathrm{a}$ & $11.95 \mathrm{~b}$ \\
2 sprays & $71.50 \mathrm{~b}$ & $14.62 \mathrm{a}$ & $10.08 \mathrm{a}$ & $8.13 \mathrm{~b}$ & $32.85 \mathrm{a}$ & $11.33 \mathrm{~b}$ \\
L.S.D. 0.05 & 10.28 & 0.36 & 0.06 & 0.06 & 0.39 & 1.56 \\
\hline Varieties & & & & & & $33.16 \mathrm{a}$ \\
\hline Giza 843 & $85.17 \mathrm{a}$ & $14.83 \mathrm{~b}$ & $10.12 \mathrm{a}$ & $8.20 \mathrm{~b}$ & $11.63 \mathrm{~b}$ \\
Giza 402 & $73.79 \mathrm{~b}$ & $14.84 \mathrm{c}$ & $10.09 \mathrm{~b}$ & $8.07 \mathrm{c}$ & $32.64 \mathrm{~b}$ & $11.22 \mathrm{~b}$ \\
Misr 1 & $84.57 \mathrm{a}$ & $15.02 \mathrm{a}$ & $10.15 \mathrm{a}$ & $8.12 \mathrm{c}$ & $33.29 \mathrm{a}$ & $10.15 \mathrm{~b}$ \\
Nubaria 3 & $69.32 \mathrm{~b}$ & $14.44 \mathrm{a}$ & $10.04 \mathrm{c}$ & $8.28 \mathrm{a}$ & $32.76 \mathrm{~b}$ & $17.49 \mathrm{a}$ \\
L.S.D. 0.05 & 4.97 & 0.16 & 0.03 & 0.07 & 0.19 & 2.03 \\
\hline
\end{tabular}

${ }^{*} \mathrm{~m}$; represents one meter ridge.

Means followed by the same letter (s) within the same column are insignificantly different at 0.05 level of probability 
Table 4.Means for plant height, faba bean vegetative weight $/ \mathrm{m}^{*}$, pod weight $/ \mathrm{m}$, O.crenata weight $/ \mathrm{m}$, total biomass $/ \mathrm{m}$ and number of spikes/plant as affected by number of glyphosate sprays and faba bean variety for the 2016 growing season (season2)

\begin{tabular}{ccccccc}
\hline No. sprays & $\begin{array}{c}\text { Plant height } \\
(\mathbf{c m})\end{array}$ & $\begin{array}{c}\text { Faba bean } \\
\text { vegetative } \\
\text { weight }\left(\mathbf{g} / \mathbf{m}^{*}\right)\end{array}$ & $\begin{array}{c}\text { Pod } \\
\text { weight } \\
(\mathbf{g} / \mathbf{m})\end{array}$ & $\begin{array}{c}\text { O.crenata } \\
\text { weight } \\
(\mathbf{g} / \mathbf{m})\end{array}$ & $\begin{array}{c}\text { Total } \\
\text { biomass } \\
(\mathbf{g} / \mathbf{m})\end{array}$ & $\begin{array}{c}\text { No. of } \\
\text { O.crenata } \\
\text { spikes/plant }\end{array}$ \\
\hline Control & $83.99 \mathrm{a}$ & $16.71 \mathrm{a}$ & $12.62 \mathrm{ab}$ & $10.93 \mathrm{a}$ & $40.26 \mathrm{ab}$ & $70.37 \mathrm{a}$ \\
1 spray & $77.26 \mathrm{a}$ & $18.13 \mathrm{a}$ & $15.78 \mathrm{a}$ & $9.35 \mathrm{ab}$ & $43.26 \mathrm{a}$ & $53.33 \mathrm{ab}$ \\
2 sprays & $77.38 \mathrm{a}$ & $15.52 \mathrm{a}$ & $12.46 \mathrm{ab}$ & $7.51 \mathrm{bc}$ & $35.49 \mathrm{bc}$ & $50.60 \mathrm{ab}$ \\
3 sprays & $77.50 \mathrm{a}$ & $15.66 \mathrm{a}$ & $10.06 \mathrm{~b}$ & $6.37 \mathrm{c}$ & $32.08 \mathrm{c}$ & $35.92 \mathrm{~b}$ \\
L.S.D. 0.05 & 16.19 & 5.20 & 3.75 & 2.35 & 6.79 & 30.48 \\
\hline Varieties & & & & & & \\
\hline Giza 843 & $89.75 \mathrm{a}$ & $22.53 \mathrm{a}$ & $21.41 \mathrm{ab}$ & $12.33 \mathrm{a}$ & $56.27 \mathrm{a}$ & $63.62 \mathrm{abc}$ \\
Giza 402 & $79.90 \mathrm{bc}$ & $12.86 \mathrm{~b}$ & $11.56 \mathrm{c}$ & $7.40 \mathrm{c}$ & $31.81 \mathrm{bc}$ & $50.30 \mathrm{bc}$ \\
Misr 1 & $74.17 \mathrm{~cd}$ & $15.07 \mathrm{~b}$ & $18.06 \mathrm{~b}$ & $3.03 \mathrm{~d}$ & $36.17 \mathrm{~b}$ & $11.38 \mathrm{~d}$ \\
Misr 3 & $85.87 \mathrm{ab}$ & $24.74 \mathrm{a}$ & $23.24 \mathrm{a}$ & $8.41 \mathrm{bc}$ & $56.39 \mathrm{a}$ & $40.35 \mathrm{c}$ \\
Nubaria 1 & $73.13 \mathrm{~d}$ & $15.14 \mathrm{~b}$ & $3.20 \mathrm{~d}$ & $9.51 \mathrm{abc}$ & $27.85 \mathrm{bc}$ & $74.91 \mathrm{a}$ \\
Nubaria 3 & $74.79 \mathrm{~cd}$ & $13.83 \mathrm{~b}$ & $7.80 \mathrm{~cd}$ & $8.23 \mathrm{bc}$ & $29.87 \mathrm{bc}$ & $59.20 \mathrm{abc}$ \\
Giza 3 & $75.63 \mathrm{~cd}$ & $11.38 \mathrm{~b}$ & $3.81 \mathrm{~d}$ & $10.86 \mathrm{ab}$ & $26.06 \mathrm{c}$ & $68.13 \mathrm{ab}$ \\
L.S.D. 0.05 & 6.64 & 4.84 & 4.82 & 3.34 & 8.50 & 23.75 \\
\hline
\end{tabular}

${ }^{*} \mathrm{~m}$; represents one meter ridge.

Means followed by the same letter (s) within the same column are insignificantly different at 0.05 level of probability.

number of spray treatments compared to the control. In our study, however, reduction in yield compared to the control amounted to $0.3 \%$ in season 1 after two sprays and $20.3 \%$ in season 2 after three sprays (Tables 3 and 4),indicating phytotoxicity. This controversy is rather expected since the biological relationship between the host and parasite is too complex to show reliability or repeatability across environments and years, however, possible logical explanations to the effect of glyphosate on faba bean yield will be further discussed.

Hormesis is defined as stimulation of growth by "subtoxic" concentrations of a toxin (Duke et al. 2006). Glyphosate hormesis reported by Velini et al. (2008) in maize and soybean occurred between 1.8-36g a.i./ha, and phytotoxicity started at the rate of $72 \mathrm{~g}$ a.i./ha. In faba bean, El-Shahawy and Sharara (2011), in a two year experiment using the cultivar Aquadulce, observed hormesis in plant height, pod number, pod weight and seed yield/plant at the rate of 13.3-26.6g a.i./ha sprayed once. The increase in yield due to hormesis amounted to 37 to $39 \%$ compared to the control depending on the year. No hormesis was observed after the second spray treatment in both years using the same rate or at the higher rates $(53.3,106.7$ and $213.3 \mathrm{~g}$ a.i./ha), indicating phytotoxicity. Thus hormesis as an explanation for increase in yield due to the rates employed in the previously mentioned studies could definitely be excluded. One reason why some studies, including the one presented here, observed no increase in faba bean yield after glyphosate spraying might be related to the possibility of encountering an aggressive O.crenata accession that shows high number of parasite attachments and strong shifting of the photo-assimilate balance towards its tubercles than to the pods. Radwan et al. (1988) and Nawar et al. (1999) have recognized variation in aggressiveness among O.crenata accessions in Egypt. Mesa-Garcia and Garcia-Torres (1985), reported lack of parasite control and yield improvement in one location (Trinidates), where glyphosate rate of $120 \mathrm{~g}$ a.i./ha was required to achieve similar results to that of the other 3 locations (already controlled at $60 \mathrm{~g}$

a.i./ha), although the number of infestations in that specific location was least, amounting to less than 20 infections $/ \mathrm{m}$ in the unsprayed control. A second and more obvious reason could be related to the size of the parasite seed bank in the fields where the different studies have been executed. Mesa-Garcia and GarciaTorres (1984) predicted a 50\% reduction in faba bean seed yield with only 4 parasite attachments. Muller and Distler (1991) and Sauerborn et al. (1989) indicated that the poor results of glyphosate application in severely infested sites may be attributed to the large number of parasite attacks that compete for the available glyphosate to the extent that each receives subtoxic levels. Accordingly, in the study presented here, a large number of viable infections were still attached to the host roots even after three sprays and consequently no improvement in yield was achieved. The number of O.crenata spikes in the control plots for the studies of El-Metwally et al. (2013), Ghalwash et al. (2012) and Kandil et al. (2015), using the same rate of glyphosate 
employed in this study, were $36.3,15$ and 5.3 spikes $/ \mathrm{m}^{2}$, respectively. Those spikes were reduced to $6.3,4.8$ and 0.82 spikes $/ \mathrm{m}^{2}$ after the maximum number of sprays employed in each of the mentioned studies, respectively. In the study presented here, 15 and 70 spikes/plant (75 and 350 spikes $/ \mathrm{m}$ considering 5 plants $/ \mathrm{m}^{2}$ ) were recorded for the control in seasons 1 and 2, respectively. This number was reduced to 11 and 36 spikes/plant (55 and 180 spikes $/ \mathrm{m}^{2}$ ) for the same seasons, respectively, when two and three glyphosate sprays were applied, respectively (Tables 3 and 4). This probably clarifies why farmers have not been adopting glyphosate for O.crenata management after the parasite seed bank in their fields has reached a level whereby no improvement in seed yield could be achieved.

\section{Effect of faba bean varieties:}

The results presented here have shown that the resistant varieties generally harbored less number of O.crenata spikes compared to the susceptible varieties (Tables 3 and 4) except in season 2 where Giza 843 harbored 63.62 spikes/plant, that were statistically insignificant from 59.2 and 68.13 harbored by Nubaria 3 and Giza 3, respectively (Table 4). The least number of spikes/plant was observed for the resistant variety Misr 1 in both seasons although not significantly different from Giza 843 and Giza 402 in season 1 (Table 3). A similar trend was recorded for the amount of dry matter accumulated by the parasite in season 2 (Table 4), where the highest $O$.crenata dry weight $/ \mathrm{m}$ was recorded for the resistant variety Giza $843(12.33 \mathrm{~g})$, which was not statistically different from the susceptible Nubaria 1(9.51g) and Giza 3 (10.86g). Again, Misr 1 showed statistically the least amount of dry matter accumulated by the parasite $(3.03 \mathrm{~g}$ ) in season 2 . Regarding faba bean performance, plant height and vegetative weight varied among varieties with Giza 843 and Misr 1 in season 1 and Giza 843 and Misr 3 in season 2 out-performing the other varieties. As to pod weight $/ \mathrm{m}$, the resistant varieties out-yielded the susceptible ones in both seasons, where Giza 843 and Misr 1 yielded $10.12 \mathrm{~g} / \mathrm{m}$ and $10.15 \mathrm{~g} / \mathrm{m}$ in season 1, respectively and Giza 843 and Misr 3 yielding $21.41 \mathrm{~g} / \mathrm{m}$ and $23.24 \mathrm{~g} / \mathrm{m}$ in season 2 , respectively. The least yielding varieties were Nubaria $3(10.04 \mathrm{~g} / \mathrm{m})$ in season 1 and Nubaria 3, Giza 3 and Nubaria 1, yielding 7.8, 3.8 and $3.2 \mathrm{~g} / \mathrm{m}$ in season 2, respectively. Results also demonstrated that when it comes to yield under O.crenata infestation, the resistant varieties Giza 843, Misr 1 and Misr 3 represent the best option. Giza 402 is the progenitor of Giza 843, the latter being an improved selection of Giza 402 (Zeid et al. 2009), that was seen here to perform much poorer than other resistant varieties. Giza 402 is no longer on the market and is available only for research purposes. One disadvantage of Giza 843, however, is that when compared to the recent "Misr" varieties, it harbors more number of spikes than Misr 1 (82\%) and Misr 3 (37\%). Misr 1 harbors $72 \%$ less spikes than Misr 3, but Misr 3 out-yields Misr 1 by 22\% (Table 4). These observations demonstrated that the breeding program in Egypt succeeded in selecting a new source of resistance, from which the Misr varieties were developed (Attia et al. 2013), other than the originally known "Giza 402". This new source was characterized by less number of emerged spikes and less photo-assimilates portioned to the parasite, providing the farmer with better yields and less emerging parasite spikes.

The estimated reduction in pod yield, solely due to O.crenata infestation, was calculated in season 2 to be 26, 42, 58 and 80\% for Giza 843, Giza 402, Nubaria 3 and Nubaria 1, respectively (data not shown). This reduction in yield was not improved with glyphosate sprays as indicated here and this explains why farmers abandon faba bean growing. Even a resistant variety coupled with glyphosate treatment, in best scenarios, means $26 \%$ loss in yield in addition to deposition of a new fresh seed load added to the already existing seed bank. These observations are in agreement with ElRokiek et al. (2015), where despite yield improvement of $58 \%$ due to glyphosate spraying, compared to the control, a $28 \%$ reduction in yield was still observed compared to O.crenata free conditions. With no improvement in faba bean yield compared to the control after glyphosate spraying and with the health risks the herbicide pauses to human health (Zhang et al. 2019); we do not recommend glyphosate as a control method for O.crenata in faba bean fields.

\section{CONCLUSIONS}

The new faba bean resistant variety "Misr 3" was seen here as a very promising variety, combining both good yield and low number of emerged spikes compared to the older varieties Giza 843 and Misr 1. Furthermore, the available technology for combating O.crenata in faba bean, represented here by the available resistant varieties coupled with glyphosate application, was not successful in either improving farmers' yield or eliminating the load of parasite seeds added to the already existing seed bank in heavily infested soils. It is also apparent that farmers are following the correct track by halting faba bean growing in infested soils until the parasite seed bank is depleted or other future successful technologies become available for application. Considering the added costs of glyphosate spraying and the serious health issues recently related to exposure to the herbicide, it is safer and more feasible to grow faba bean in O.crenata free soils provided that measures are 
undertaken to prevent spread of the parasite in these areas in the future.

\section{ACKNOWLEDGEMENT}

This work was partially funded by the project: AGRV-11, Research Enhancement Program, Alexandria University, Alexandria, Egypt.

\section{REFERENCES}

Abang M.M., B. Bayaa, B. Abu-Irmaileh and A. Yahyaoui. 2007. A participatory farming system approach for sustainable broomrape (Orobanche spp.) management in the Near East and North Africa. Crop Prot. 26(12):17231732.

Arjona-Berral A., J. Mesa-Garcia and L. Garcia-Torres. 1990. Distribution of ${ }^{14} \mathrm{C}$ glyphosate in legumes parasitised by Orobanche crenata. Weed Res. 30(1):53-59.

Attia S.M., M.M. El-Hady, H.A. Saber, M.A. Omer, S.A. Khalil, S.A. Mahmoud, A.A. Ashrei, M.A. Ibrahim, Z.E. Ghareeb, T.S. El-Marsafawy and E.H. El-Harty. 2013. Misr 3, a new Orobanche tolerant faba bean variety. Egypt J. Plant Breed. 203:1-21.

CAAES. 2014. Central Administration for Agricultural Extension Service, Egypt, (In Arabic). Retrieved from http://www.caaes.org/topics/146444\#http://www.caaes.org /downloads/84427 [26 October 2018].

Duke S.O., N. Cedergreen, E.D. Velini and R.G. Belz. 2006. Hormesis: is it an important factor in herbicide use and allelopathy? Outlooks on Pest Manag. 17(1):29-33.

El-Metwally I., T. El-Shahawy and M. Ahmed. 2013. Effect of sowing dates and some broomrape control treatments on faba bean growth and yield. J. App. Sci. Res. 9(1):197204.

El-Rokiek K.G., I. El-Metwally, N.K. Messiha, S.E.S. Amin. 2015. Controlling Orobanche crenata in faba bean using the herbicides glyphosate and imazapic with some additives. Int. J. Chem. Tech. Res. 8(10):18-26.

El-Shahawy T.A. and F.A.A. Sharara. 2011. Hormesis influence of glyphosate in between increasing growth, yield and controlling weeds in faba bean. J. Am. Sci. 7(2):139-144.

FAOSTAT. 2019. Food and Agriculture Organization, http://faostat.fao.org/.

Ghalwash A.M., H.S. Gharib and A.E. Khaffagy. 2012. Integrated broomrape (Orobanche crenata Forsk.) control in faba bean (Vicia faba L.) with nitrogen fertilizer, intercropping and herbicides. Egypt J. Agron. 34(2):301319.

Jacobsohn R. and Y. Kelman. 1980. Effectiveness of glyphosate in broomrape (Orobanche spp.) control in four crops. Weed Sci. 28(6):692-699.

Kandil E.E.E., A.M. Kordy and A.A.A. Zied. 2015. New approach for controlling broomrape plants in faba bean. Alex. Sci. Exch. J. 36(3):281-291.
Manschadi A.M., J. Sauerborn, J. Kroschel, and M.C. Saxena. 1997. Effect of plant density on grain yield, root-length density and Orobanche crenata infestation in two faba bean genotypes. Weed Res. 37(1):39-49.

Mesa-Garcia J., A. De Haro and L. Garcia-Torres. 1984. Phytotoxicity and yield response of broad bean (Vicia faba) to glyphosate. Weed Sci. 32(4):445-450.

Mesa-Garcia J. and L. Garcia-Torres. 1984. A competition index for Orobanche crenata Forsk effects on broad bean (Vicia faba L.). Weed Res. 24(6):379-382.

Mesa-Garcia J., and L. Garcia-Torres. 1985. Orobanche crenata (Forsk) control in Vicia faba (L.) with glyphosate as affected by herbicide rates and parasite growth stages. Weed Res. 25(2):129-134.

Misganaw M. 2016. Integrated weed (Orobanche crenata) management on faba bean. J. Am. Sci. 1(2):29-34.

Muller F. and B. Distler. 1991. Translocation of glyphosate in the hostparasite system Vicia faba and Orobanche crenata. In: Wegmann K. and Musselman L.J. (eds) Progress in Orobanche research. Proceeding of the international workshop on Orobanche research, Obermarchtal, 1989, Ederhard-Karls- Universitaet, Tubingen, FRG., pp 226-233.

Nadal S., M.T. Moreno, J.I. Cubero and D. Rubiales. 2005. Determinate faba bean young pod response to glyphosate and crenate broomrape (Orobanche crenata). J. Sust. Agr. 25(4):19-27.

Nassib A.M., A.A. Ibrahim and S.A. Khalil. 1982. Breeding for resistance to Orobanche. Faba bean improvement. Springer, pp 199-206.

Nassib A.M., S.A. Khalil and A.H.A. Hussein. 1991. Faba bean production and consumption in Egypt. Present status and future prospects of faba bean production and improvement in the Mediterranean countries:127-131.

Nawar A., M.M. Zeid, F.M.F. Zaitoun, M.A. Madkour and Y.S. Koraiem. 1999. Variation among three Orobanche crenata accessions in their virulence in relation to growth and yield characters of the faba bean cultivars Giza 3 and Giza 429. In: Kroschel M. and Abderabihi H.B. (eds) Advances in parasitic weed control at on-farm level VolII Joint action to control Orobanche in the WANA region Magraf Verlag, Weikersheim, Germany, pp 215-225.

Parker C. 2013. The status of Orobanche crenata in UK. In: Building a new research alliance to reclaim faba bean production area abandoned to Orobanche, Rabat, Marocco, p 12.

Poutney N. 2014. Faba bean marketing and the Middle East. GRDC Retrieved from http://grdc.com.au [26 October 2018].

Radwan M.S., M.M.F. Abdalla, G. Fischbeck, A.A. Metwally and D.S. Darwish. 1988. Variation in reaction of faba bean lines to different accessions of Orobanche crenata Forsk. Plant Breed. 101(3):208-216. 
SAS. 2007. SAS Institute, Inc. SAS Technical Report SAS/STAT Software; Changes and Enhancements Users Guide. Volume 2, Version 9.1.3, Fourth Edition, Cary, NC: SAS Institute Inc.

Sauerborn J., M.C. Saxena and A. Meyer. 1989. Broomrape control in faba bean (Vicia faba L.) with glyphosate and imazaquin. Weed Res. 29(2):97-102.

Shaban S.A., A.H. El-Hattab, E.A. Hassan and M.R. AboElSuoud .1987. Recovery of faba bean (Vicia faba L.) plants as affected by glyphosate. J. Agr. Crop Sci. 158(5):294-303.

Velini E.D., E. Alves, M.C. Godoy, D.K. Meschede, R.T. Souza, and S.O. Duke. 2008. Glyphosate applied at low doses can stimulate plant growth. Pest Manag. Sci. 64(4):489-496.

Zahran M.K., I. El Nasr, F.H. Farag and M.A. Korollos. 1980. Chemical control of Orobanche crenata in Vicia faba. FABIS (ICARDA):47-49.

Zeid M., S. Mitchell, W. Link, M. Carter, A. Nawar, T. Fulton, and S. Kresovich. 2009. Simple sequence repeats (SSRs) in faba bean: new loci from Orobanche resistant cultivar 'Giza 402'. Plant Breed. 128(2):149-155.

Zhang, L., I. Rana, E. Taioli, R.M. Shaffer, and L. Sheppard. 2019. Exposure to glyphosate-based herbicides and risk for non-hodgkin lymphoma: A meta-analysis and supporting evidence. Mutation Res./Rev. in Mutation Res. https://doi.org/10.1016/j.mrrev.2019.02.001.

\section{الملخص العربي}

\section{إستجابة بعض أصناف الفول البلدى لمستويات الرش بالجليفوسات تحت ظروف الإصابة الشديده}

\section{بالأهالو}

محمود محمد زيد - منى محمد حمبد

(بدون رش) حتى مع أكثر الأصناف مقاومة للهالوك فى مئ مصر(جيزه سعی ومصر ا و مصرس). و بناء عليه

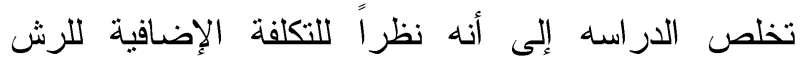

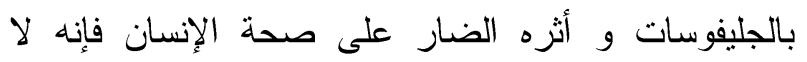
ينصح بإستخدام المبيد لمكافحة الهالوك و تحت الظروف الحالية من إصابة شديدة ببذور الهالوك فى حقول الفلاحين فإنه يفضل الإمتتاع عن زراعة محاصيل البقول الغذائية الثتوية التى تصاب بهالوك الفول البلدى و إتباع طرق المكافحة المتكاملة الأخرى و التى لا تتطوى على زراعة البقوليات والتى من شأنها إستنز اف محتوى التزبة من بذور الهالوك لحين ظهور تقنيات أحدث فاعليه لمقاومة الطفيل حتى لا نستمر فى إضافة بذور هالوك جديدة مع كل زر اعة للبقوليات كذلك أوضحت الدراسة أن صنف الفول البلدى لبع مصر r هو صنف واعد جداً لمقاومة الهالوك يتميز بمحصول مرتفع و ظهور عدد أقل من الثماريخ الزهرية

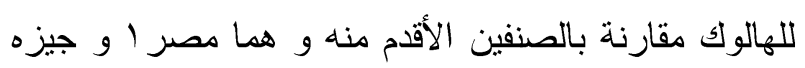
$. \wedge \leqslant \mu$
يعتبر هالوك الفول المتطفل من أخطر الحشائش التى تؤثز على زراعة الفول البلدى و الذى لم تعد أضراره

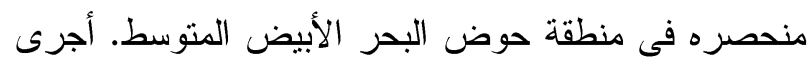
هذا البحث بهدف دراسة تأثير عدد مرات رش الجليفوسات بمعدل ^ا جرام مادة فعالة/هكتار على نمو و إنتاجية مجموعة من أصناف الفول البلدى متباينة فى مقاومتها للهالوك تحت ظروف الزراعة الو اقعية بأرض الفلاح. و

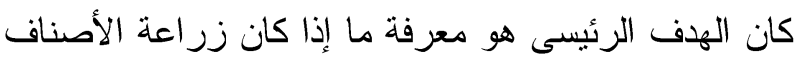
المقاومة و بالرش بالجليفوسات يمكن الإعتماد عليهما معاً كطريقة فعالة للقضاء على الهالوك. و قد أظهرت النتائج أنه تحت الظروف الحالية لأر اضى الفلاحين المصابة بشدة بالهالوك فإن الرش بالمبيد أظهرقدره و اضحة فى خفض عدد الثماريخ الزهرية النامية فوق سطح التربة من 11 1؟ \% و كذلك خفض كمية الغذاء الممثل الذى تحصل عليه الطفيل من الفول البلدى عند الحصاد من ا-r؟؛\% حسب الصنف المنزرع و كان الإنخفاض مرتبطاً بعدد معاملات

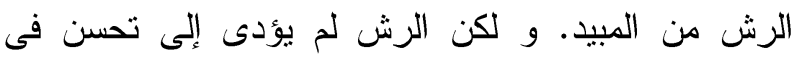
إنتاجية الفول تحت ظروف الإصابة مقارنة بالكنترول 